\title{
CLINICOPATHOLOGICAL EVALUATION OF NECK MASSES- A DESCRIPTIVE STUDY
}

\author{
Manoj Kumar Naik1, Ranjan Kumar Guru², Pradumna Kishore Panda ${ }^{3}$ \\ ${ }^{1}$ Assistant Professor, Department of Anatomy, MKCG Medical College, Berhampur, Odisha. \\ ${ }^{2}$ Assistant Professor, Department of ENT, VSSIMSAR, Burla, Sambalpur, Odisha. \\ ${ }^{3}$ ENT Specialist, District Head Quarter Hospital, Kalahandi, Odisha.
}

\section{ABSTRACT}

\section{BACKGROUND}

There is a wide variation in the presentation of neck masses in respect to its site of origin and clinical presentation as well as nature of progression of disease. This study is performed to have an idea about the prevalence of various neck masses according to age, sex and site, so that it will help us in diagnosing the neck masses.

\section{MATERIALS AND METHODS}

This study is performed in the Department of ENT, VSS Medical College, Burla from January 2015 to July 2015 over 200 patients presenting with neck mass.

Study Design- Descriptive study.

\section{RESULTS}

Cervical lymphadenopathy was found in 82 patients. Out of these cervical lymph nodes, tubercular lymphadenopathy was found in 82 cases. Among the thyroid masses, colloid goitre was found in 46 cases. In salivary gland tumours, pleomorphic adenoma of parotid was found in 11 cases. 89.5\% neck masses are benign in nature.

\section{CONCLUSION}

Cervical lymphadenopathy was the most commonly encountered neck mass. Out of these cervical lymph nodes, tubercular lymphadenopathy was most common. Among the thyroid masses, colloid goitre was most common. In salivary gland tumours, pleomorphic adenoma of parotid was most common. Most of the neck masses [89.5\%] are benign in nature.

\section{KEYWORDS}

Neck Masses, Common Neck Masses, Neck Mass Evaluation.

HOW TO CITE THIS ARTICLE: Naik MK, Guru RK, Panda PK. Clinicopathological evaluation of neck masses- A descriptive study. J. Evolution Med. Dent. Sci. 2017;6(79):5594-5597, DOI: 10.14260/jemds/2017/1214

\section{BACKGROUND}

The evaluation of a neck mass is a common clinical condition to which an ENT clinician routinely encounters. The neck is one of the vital parts of human body. It carries a number of important structures inside, like major blood vessels, nerve fibres, lymphatics, aerodigestive tracts, cervical spine with the spinal cord and many exocrine \& endocrine glands. Neck masses are one of the most common ailments of the neck presented to the ENT Department throughout the world. Wide variations in the site of origin in neck, clinical presentation as well as nature and progression of disease process in patients with neck masses presents challenge to the otolaryngologists in terms of their early accurate diagnostics and timely effective and specific management. In the developed nations, the rapidly growing urban dwellings industrialisation and environmental pollution lead to the increased incidence of malignancies in the head \& neck region. ${ }^{[1]}$ In the developing and underdeveloped nations,

'Financial or Other Competing Interest': None.

Submission 19-07-2017, Peer Review 19-09-2017

Acceptance 25-09-2017, Published 30-09-2017.

Corresponding Author:

Dr. Ranjan Kumar Guru,

Assistant Professor,

Department of ENT,

VSSIMSAR (Veer Surendra Sai Institute of Medical

Science \& Research), Burla-768017, Dist. Sambalpur,

Odisha.

E-mail:dr.rkguru@gmail.com

DOI: 10.14260/jemds/2017/1214 infectious diseases are a major cause of neck masses due to lack of nutrition and overcrowding.[2] Malignancies of neck region are also common due to addiction to smoking and environmental pollution in these countries.[1] Fine needle aspiration cytology (FNAC) is a simple, quick and cost effective method for simple superficial masses found in the neck. It causes minimal trauma to the patient and carries virtually no risk of complication. ${ }^{[3]}$ Masses located within the region of head and neck including salivary glands and thyroid masses can be readily diagnosed using this technique. ${ }^{[4,5]}$ An early differentiation of benign from malignant pathology greatly influences the planned treatment.[6]

\section{Aim of the Study}

To have an idea about the prevalence of various neck masses according to age, sex and site, so that it will help us in diagnosing the neck mass.

\section{MATERIALS AND METHODS}

The present descriptive study was undertaken in the Department of ENT of VSS Medical College \& Hospital, Burla, Sambalpur, Odisha, during the period from January 2015 to July 2015. All the cases of neck masses coming to the Department of ENT were taken for study. Their detailed history was taken. Then a detailed general examination was done. The neck masses were examined by standard clinical methods. All routine laboratory investigations were carried out. Special tests like Mantoux test, chest X-ray, Thyroid profile, FNAC of neck mass, incisional or excisional biopsy followed by histopathological study were carried out in 
suspected cases. Out of above 200 cases, open biopsy \& HP study was undertaken in 80 cases. From FNAC and biopsy of suspected cases, the various types of neck masses found are given in the observation tables.

\section{Inclusion Criteria}

All cases of neck masses coming to ENT OPD within 5-65 years either male or female are included in the study. Consent was taken from all cases. In case of minors, their guardians gave the consent.

\section{Exclusion Criteria}

Patients of age group less than 5 years and more than 65 years are excluded from the study. Only some cases of obesity within 5 to 65 years who had presented with submental swelling which was due to excess amount of fat were excluded from this study. Due to laxity of skin and excess amount of fat, the obese patients have perceived it as a neck mass and presented to ENT OPD. For this reason, they were excluded from our study.

\section{RESULTS}

\begin{tabular}{|c|c|c|c|}
\hline $\begin{array}{l}\text { Sl. } \\
\text { No }\end{array}$ & Type of Neck Mass & $\begin{array}{c}\text { No. of Cases } \\
(n=200)\end{array}$ & $\%$ \\
\hline 1 & Cervical lymphadenopathy & 82 & 41 \\
\hline 2 & Thyroid masses & 71 & 35.5 \\
\hline 3 & Salivary gland masses & 23 & 11.5 \\
\hline 4 & Miscellaneous neck masses & 24 & 12 \\
\hline & Total & 200 & 100 \\
\hline
\end{tabular}

The site of distribution of neck masses and frequency of lesion at these sites are shown in Table 1 . The most common are found to be cervical lymph nodes (41\%) followed by thyroid masses (35.5\%).

\begin{tabular}{|c|c|c|c|}
\hline $\begin{array}{l}\text { Sl. } \\
\text { No }\end{array}$ & $\begin{array}{c}\text { Type of Cervical } \\
\text { Lymphadenopathy }\end{array}$ & $\begin{array}{c}\text { No. of Cases } \\
(n=82)\end{array}$ & $\%$ \\
\hline 1 & $\begin{array}{c}\text { Tubercular } \\
\text { lymphadenopathy }\end{array}$ & 38 & 46.3 \\
\hline 2 & Reactive hyperplasia & 28 & 34.1 \\
\hline 3 & Metastatic carcinoma & 12 & 14.6 \\
\hline 4 & Lymphoma & 4 & 4.9 \\
\hline & Total & 82 & 100 \\
\hline
\end{tabular}

Table 2 shows the distribution of the types of cervical lymph node masses. According to our finding, tubercular lymphadenopathy was the most common lesion (46.3\%) followed by reactive hyperplasia (34.1\%). Metastatic carcinoma $(14.6 \%)$ was the $3^{\text {rd }}$ most common finding followed by lymphoma (4.9\%).

\begin{tabular}{|c|c|c|c|}
\hline $\begin{array}{l}\text { Sl. } \\
\text { No }\end{array}$ & $\begin{array}{c}\text { Type of Thyroid } \\
\text { Masses }\end{array}$ & $\begin{array}{c}\text { No. of Cases } \\
(n=71)\end{array}$ & Percentage \\
\hline 1 & Colloid goitre & 46 & 64.8 \\
\hline 2 & Thyroiditis & 19 & 26.8 \\
\hline 3 & Follicular adenoma & 3 & 4.2 \\
\hline 4 & Thyroid carcinoma & 3 & 4.2 \\
\hline & Total & 71 & 100 \\
\hline
\end{tabular}

Table 3 shows incidence of thyroid masses. Colloid goitre was the most common (64.8\%) type of thyroid mass followed by thyroiditis (26.8\%). Follicular adenoma \& thyroid carcinoma are the third most common type (4.2\% each). Out of 19 cases of thyroiditis, 14 cases are Hashimoto's thyroiditis and 5 cases are lymphocytic thyroiditis. Out of the 3 cases of thyroid carcinoma, 2 cases of papillary and one case of anaplastic carcinoma were noted.

\begin{tabular}{|c|c|c|c|}
\hline $\begin{array}{c}\text { Sl. } \\
\text { No }\end{array}$ & $\begin{array}{c}\text { Type of Salivary } \\
\text { Gland Mass }\end{array}$ & $\begin{array}{c}\text { No. of Cases } \\
(\mathbf{n = 1 6 )}\end{array}$ & Percentage \\
\hline 1 & $\begin{array}{c}\text { Pleomorphic adenoma } \\
\text { of parotid gland }\end{array}$ & 11 & 47.8 \\
\hline 2 & $\begin{array}{c}\text { Sialadenitis of } \\
\text { submandibular gland }\end{array}$ & 8 & 34.8 \\
\hline 3 & $\begin{array}{c}\text { Sialadenitis of } \\
\text { parotid gland }\end{array}$ & 2 & 8.7 \\
\hline 4 & $\begin{array}{c}\text { Carcinoma of parotid } \\
\text { gland }\end{array}$ & 2 & 8.7 \\
\hline \multicolumn{2}{|r|}{ Table 4. Incidence of Type of Salivary Gland Masses } \\
\hline
\end{tabular}

Table 4 shows incidence of salivary gland masses of the neck. Here pleomorphic adenoma of the parotid $(47.8 \%)$ was the most common lesion followed by sialadenitis of submandibular salivary gland, carcinoma of parotid gland and sialadenitis of the parotid gland. Both cases of carcinoma of parotid were found to be mucoepidermoid carcinoma.

\begin{tabular}{|c|c|c|c|}
\hline Sl. No & $\begin{array}{c}\text { Type of Neck } \\
\text { Mass }\end{array}$ & $\begin{array}{c}\text { No. of Cases } \\
(\mathbf{n = 2 4 )}\end{array}$ & $\mathbf{\%}$ \\
\hline 1 & Sebaceous cyst & 7 & 29.2 \\
\hline 2 & Thyroglossal cyst & 7 & 29.2 \\
\hline 3 & Dermoid cyst & 5 & 20.8 \\
\hline 4 & Lipoma & 3 & 12.5 \\
\hline 5 & Fibroma & 2 & 8.3 \\
\hline \multicolumn{3}{|c|}{ Table 5. Incidence of Miscellaneous Neck Mass } \\
\hline
\end{tabular}

Table 5 shows the distribution of miscellaneous neck masses including benign \& cystic lesions of the neck. Sebaceous cyst and thyroglossal cyst were the most commonly encountered mass in our group followed by dermoid cyst, lipoma and fibroma.

\begin{tabular}{|c|c|c|c|c|c|c|}
\hline $\begin{array}{ll}\text { Sl. } \\
\text { No }\end{array}$ & $\begin{array}{c}\text { Type of } \\
\text { Neck Mass }\end{array}$ & $\begin{array}{l}\text { Total No. } \\
(n=200)\end{array}$ & $\begin{array}{c}\text { Nonmalig- } \\
\text { nant }\end{array}$ & $\%$ & $\begin{array}{c}\text { Malig- } \\
\text { nant }\end{array}$ & $\%$ \\
\hline 1 & $\begin{array}{c}\text { Cervical } \\
\text { lymphadenopathy }\end{array}$ & 82 & 66 & 33 & 16 & 8 \\
\hline 2 & Thyroid masses & 71 & 68 & 34 & 3 & 1.5 \\
\hline 3 & $\begin{array}{c}\text { Salivary gland } \\
\text { Masses }\end{array}$ & 23 & 21 & 10.5 & 2 & 1 \\
\hline 4 & $\begin{array}{c}\text { Miscellaneous } \\
\text { Masses }\end{array}$ & 24 & 24 & 12 & - & - \\
\hline & Total & 200 & 179 & 89.5 & 21 & 10.5 \\
\hline
\end{tabular}
Neck Masses

Table 6 shows the incidence of nonmalignant (89.5\%) \& malignant $(10.5 \%)$ neck masses in this series. Most common nonmalignant lesions were found in thyroid masses (34\%) followed by lymph nodes (33\%). Least common benign mass was found in cases of salivary gland lesions (10.5\%). Among the malignant neck masses, lymph node accounts for $8 \%$ of the cases followed by thyroid (1.5\%) and salivary gland mass (1\%). 


\begin{tabular}{|c|c|c|c|c|c|c|c|c|c|c|c|c|}
\hline \multirow{2}{*}{$\begin{array}{c}\text { Type of } \\
\text { Neck Mass }\end{array}$} & \multirow{2}{*}{$\begin{array}{c}\text { Total No. } \\
\text { of Cases }\end{array}$} & \multirow[t]{2}{*}{ Male } & \multirow[t]{2}{*}{$\%$} & \multirow[t]{2}{*}{ Female } & \multirow[t]{2}{*}{$\%$} & \multicolumn{7}{|c|}{ Age Incidence in years } \\
\hline & & & & & & $1-10$ & $11-20$ & $21-30$ & $31-40$ & $41-50$ & $51-60$ & $>60$ \\
\hline \multicolumn{13}{|c|}{ 1. Cervical lymphadenopathy } \\
\hline Tubercular & 38 & 16 & 42.1 & 22 & 57.9 & 2 & 14 & 10 & 6 & - & 4 & 2 \\
\hline Reactive hyperplasia & 28 & 16 & 57.1 & 12 & 42.9 & 12 & 9 & 2 & 5 & - & - & - \\
\hline Metastatic carcinoma & 12 & 6 & 50 & 6 & 50 & - & - & - & 1 & 3 & 5 & 3 \\
\hline Lymphoma & 4 & 3 & 75 & 1 & 25 & - & 2 & - & - & - & 1 & 1 \\
\hline \multicolumn{13}{|c|}{ 2. Thyroid masses } \\
\hline Colloid goitre & 46 & 12 & 26.1 & 34 & 73.9 & - & 3 & 13 & 17 & 7 & 4 & 2 \\
\hline Thyroiditis & 19 & - & - & 19 & 100 & 2 & 3 & 6 & 3 & 4 & 1 & - \\
\hline Follicular adenoma & 3 & 1 & 33.3 & 2 & 66.7 & - & - & 1 & 2 & - & - & - \\
\hline Thyroid carcinoma & 3 & 3 & 100 & - & - & - & 1 & - & 1 & 1 & - & - \\
\hline \multicolumn{13}{|c|}{ 3. Salivary gland masses } \\
\hline $\begin{array}{c}\text { Pleomorphic } \\
\text { adenoma of parotid }\end{array}$ & 11 & 2 & 18.2 & 9 & 81.8 & - & 1 & 2 & 2 & 4 & 1 & 1 \\
\hline $\begin{array}{c}\text { Sialadenitis of } \\
\text { submandibular gland }\end{array}$ & 8 & 5 & 62.5 & 3 & 37.5 & - & 1 & 3 & 1 & - & 3 & - \\
\hline Sialadenitis of parotid & 2 & 1 & 50 & 1 & 50 & - & - & - & - & - & 2 & - \\
\hline Carcinoma parotid & 2 & - & - & 2 & 100 & - & - & - & - & 2 & - & - \\
\hline \multicolumn{13}{|c|}{ 4. Miscellaneous masses } \\
\hline Sebaceous cyst & 7 & 5 & 71.4 & 2 & 28.6 & - & 3 & 3 & 1 & - & - & - \\
\hline Thyroglossal cyst & 7 & 5 & 71.4 & 2 & 28.6 & 2 & 4 & 1 & - & - & - & - \\
\hline Dermoid cyst & 5 & 2 & 40 & 3 & 60 & - & 2 & 3 & - & - & - & - \\
\hline Lipoma & 3 & 2 & 66.7 & 1 & 33.3 & - & - & - & 1 & 1 & - & 1 \\
\hline Fibroma & 2 & 1 & 50 & 1 & 50 & - & - & 1 & 1 & - & - & - \\
\hline \multicolumn{13}{|c|}{ Table 7. Age \& Sex Incidence of Neck Masses } \\
\hline
\end{tabular}

Table 7 shows the age and sex distribution of neck masses. Tubercular lymphadenopathy was most common in females, in adolescent and in young adults. Reactive hyperplasia, metastatic carcinoma \& lymphoma are more common in males. Reactive hyperplasia was more common in adolescent males whereas metastatic carcinoma and lymphoma are more common in patients above 50 years of age. Among the thyroid masses, colloid goitre, thyroiditis and follicular adenoma were more common in females and young adults whereas thyroid carcinoma was more common in males. However, in salivary masses, pleomorphic adenoma was more common in females whereas sialadenitis of the submandibular gland was more common in males. Overall, benign neck masses were found mostly in adolescent and young adults whereas malignant neck masses were most common in older age group.

\section{DISCUSSION}

Neck masses are very frequently encountered masses in the ENT Department. If it is a developing country like India, then it becomes very essential to diagnose a neck mass as there is high incidence of cervical lymphadenopathy due to TB, reactive hyperplasia \& metastatic diseases. Thyroid mass especially colloid goitre is the frequently encountered neck mass in this part of the country.

In our study, most common lesion was found to be of cervical lymphadenopathy followed by thyroid mass. In our study, tubercular lymphadenopathy was present in $46.3 \%$ of cases. This is consistent with the study of Haque MA et al (2002) (40.35\%).[7] In our study, reactive hyperplasia was found in $34.1 \%$, which is consistent with the study by Sra et al (2003) (34\%).[8] In our study, metastatic carcinoma was found in $14.6 \%$ \& lymphoma was found in $4.9 \%$. These findings are in consistent with the study of Hirachand $\mathrm{S}$ et al (2008).[9]
Most of the patients with head \& neck masses were found between 20-40 years age group. The youngest patient in the series was a 4-year-old and the oldest patient in this series was a 73-year-old. Inflammatory lesions are mostly seen in $2^{\text {nd }} \& 3^{\text {rd }}$ decades, whereas benign lesions are most common in 30-40 years age group. Malignant lesions were reported in older age groups.

The most common lesion in this series were cervical lymphadenopathy $(41 \%)$ followed by thyroid masses (35.5\%). This was consistent with findings of Frable \& Frable (1982)[10] who encountered 649 lymph node masses in their series of 1303 FNACs.

Out of the thyroid masses, colloid goitre $(64.8 \%)$ was most common followed by thyroiditis (26.8\%). This is consistent with study by Marvin et al.[11] Out of the salivary gland masses, pleomorphic adenoma $(47.8 \%)$ of parotid was the most common. This is consistent with the study by John A et al.[12]

Out of the miscellaneous neck masses, sebaceous cyst is most common. This is consistent with the study of Taiseer Hussain et al.[13] Most common benign lesions are found in thyroid, this is consistent with the study of Dean DS et al.[14]

\section{Abbreviations}

FNAC - Fine needle aspiration cytology.

HP - Histopathology.

\section{CONCLUSION}

From our present study, it can be concluded that Cervical lymphadenopathy (41\%) was the most commonly encountered neck mass followed by thyroid masses $(35.5 \%)$. Out of these cervical lymph nodes, tubercular lymphadenopathy $(46.3 \%)$ was most common followed by reactive hyperplasia (34.1\%). Among the thyroid masses, colloid goitre $(64.8 \%)$ was most common followed by 
thyroiditis (26.8\%). In salivary gland tumours, pleomorphic adenoma of parotid (47.8\%) was most common followed by sialadenitis of the submandibular salivary gland (34.8\%). Sebaceous cyst was the most common neck mass in the miscellaneous group including benign and cystic lesion of the neck. Most of the neck masses [89.5\%] are benign in nature.

\section{REFERENCES}

[1] Wong CK, Yuen-Keng NG, Vivian WYL. Cancers of the lung, head and neck on the rise: perspectives on the genotoxicity of air pollution. Chinese journal of cancer 2014;10(33):474-80.

[2] Lucumay EM, Gilyoma JM, Chalya PL, et al. Paediatric neck masses at a university teaching hospital in northwestern Tanzania: a prospective analysis of 148 cases. BMC Res Notes 2014;7:772.

[3] Singh PK, Kumar A, Kumar D. Clinicopathological study of neck masses in patients attending ENT out patient department of Rajendra institute of medical sciences. IOSR Journal of Dental and Medical Sciences 2017;16(1):38-41.

[4] Celeste NP, Williams JF. Fine needle aspiration biopsy of the head and neck. USA: Butterworth Heinemann 1996:1-13.

[5] Gamba PG, Messineo A, Antoniello LM, et al. A simple exam to screen superficial masses: fine-needle aspiration cytology. Med Pediatr Oncol 1995;24(2):97-9.
[6] Watkinson JC, Wilson JA, Gaze M, et al. Stell and Maran's Head and neck surgery. Chapter 2, Butterworth-Heinemann, oxford. $4^{\text {th }}$ edn. 2000:20-1.

[7] Haque MA, Talukdar SL. Mymen singh med. Journ 2003;2(1):113-8.

[8] Sra N, Verma SK, Singh D, et al. Incidence of lymphoma in head \& neck region. Indian Journal of otolaryngology \& Head \& Neck surgery 2003;55(4):303-5.

[9] Hirachan S, Lakhan M. Kathmandu university of med. Journ 2009;7(26):139-42.

[10] Frable WJ, Frable MA. Thin needle aspiration biopsy: the diagnosis of head \& neck tumors revisited. Cancer 1979;43(4):1541-8.

[11] Rallison ML, Dobyns BM, Meikle AW, et al. Natural history of thyroid abnormalities: Prevalence, incidence, and regression of thyroid diseases in adolescents and young adults. The American Journal of medicine 1991;91(4):363-70.

[12] Pinkston JA, Cole P. Incidence rates of salivary gland tumors: results from a population-based study. Otolaryngology-Head and Neck Surgery 1999;120(6):834-40.

[13] Hussain T, Al-Khateeb, Al-Masri NM, et al. Cutaneous cysts of the head and neck. Journal of oral and maxillofacial surgery 2009;67(1):52-7.

[14] Dean DS, Gharib H. Epidemiology of thyroid nodules. Best Pract Res Clin Endocrinol Metab 2008;22(6):90111. 